\title{
Retraction Note to: Degradation of long non-coding RNA-CIR decelerates proliferation, invasion and migration, but promotes apoptosis of osteosarcoma cells
}

\author{
Shiwei Liu' ${ }^{1,2}$, Jingchao Li ${ }^{1,2}$, Liang Kang ${ }^{1,2}$, Yueyang Tian ${ }^{1,2}$ and Yuan Xue ${ }^{1,2^{*}}$ (I)
}

\section{Retraction to: Cancer Cell Int (2019) 19:349 https://doi.org/10.1186/s12935-019-1076-7}

The Editors-in-Chief have retracted this article. After publication, concerns were raised about the images presented in Figs. 2-8. Specifically:

Repeated motifs are present in colony formation images in Figs. 2a and 3a;

Repeated scatter patterns of data points appear in Figs. $4 \mathrm{~b}$ and $5 \mathrm{~b}$;

Cell images in various panels of Figs. $6 a$ and 7a partially overlap;

Tumor images appear to be presented on an artificial background in Figs. 8a and 8c.

The corresponding author has stated the original data is no longer available. The Editor-in-Chief therefore no longer has confidence in the presented data.

All authors agree to this retraction.

\begin{abstract}
Author details
'Department of Orthopaedics, Tianjin Medical University General Hospital, 154 Anshan Road, Heping District, Tianjin 300052, China. ${ }^{2}$ Tianjin Key Laboratory of Spine and Spinal Cord, Tianjin Medical University General Hospital, 154 Anshan Road, Heping District, Tianjin 300052, China.
\end{abstract}

Accepted: 13 January 2022

Published online: 24 January 2022

\section{Publisher's Note}

Springer Nature remains neutral with regard to jurisdictional claims in published maps and institutional affiliations. to the material. If material is not included in the article's Creative Commons licence and your intended use is not permitted by statutory regulation or exceeds the permitted use, you will need to obtain permission directly from the copyright holder. To view a copy of this licence, visit http://creativecommons.org/licenses/by/4.0/. The Creative Commons Public Domain Dedication waiver (http://creativecommons.org/publicdomain/zero/1.0/) applies to the data made available in this article, unless otherwise stated in a credit line to the data. 